\title{
MECHANICAL PROPERTIES OF ANODIC TITANIUM DIOXIDE NANOSTRUCTURES
}

\author{
MEHANSKE LASTNOSTI NANOSTRUKTUR TITANOVEGA \\ DIOKSIDA
}

\author{
Mukta Kulkarni' ${ }^{1}$, Josef Šepitka ${ }^{2}$, Ita Junkar ${ }^{3}$, Metka Benčina ${ }^{1,3}$, Niharika Rawat ${ }^{1}$, \\ Anca Mazare ${ }^{4}$, Chandrashekhar Rode ${ }^{5}$, Suresh Gokhale ${ }^{6}$, Patrik Schmuki ${ }^{4}$, \\ Matej Daniel ${ }^{2}$, Ales Iglič ${ }^{*}$ \\ ${ }^{1}$ Laboratory of Physics, Faculty of Electrical Engineering, University of Ljubljana, Tržaška 25, 1000 Ljubljana, Slovenia \\ ${ }^{2}$ Department of Mechanics, Biomechanics and Mechatronics, Faculty of Mechanical Engineering, Czech Technical University in Prague, \\ Technicka 4, Prague 16607, Czech Republic \\ ${ }^{3}$ Department of Surface Engineering and Optoelectronics, Jožef Stefan Institute, Jamova 39, 1000 Ljubljana, Slovenia \\ ${ }^{4}$ Department of Materials Science and Engineering, WW4-LKO, University of Erlangen Nürnberg, Martensstrasse 791058 , \\ Erlangen, Germany \\ ${ }^{5}$ Chemical Engineering and Process Development Division, CSIR-National Chemical Laboratory, Dr. Homi Bhabha Road, Pune, India 411008 \\ ${ }^{6}$ Physical \& Materials Chemistry Division, CSIR-National Chemical Laboratory, Dr. Homi Bhabha Road, Pune, India 411008
}

Prejem rokopisa - received: 2020-06-09; sprejem za objavo - accepted for publication: 2020-07-25

doi:10.17222/mit.2020.109

Highly ordered and uniform titanium dioxide $\left(\mathrm{TiO}_{2}\right)$ nanotubes $(\mathrm{NTs})$ with different morphologies $(15 \mathrm{~nm}, 50 \mathrm{~nm}$ and $100 \mathrm{~nm}$ in diameter) were prepared by the electrochemical anodization of $\mathrm{Ti}$ substrates. The $\mathrm{TiO}_{2} \mathrm{NTs}^{\prime}$ surface properties were characterized by X-ray diffraction (XRD) spectroscopy, Raman spectroscopy, scanning electron microscopy (SEM) and atomic force microscopy (AFM). The elastic modulus $(E)$ and the Vickers hardness $(\mathrm{HV})$ of the Ti foil and of the different-morphology TiO NTs were evaluated with the nano-indentation technique. $E$ and HV increase with the decreasing length/diameter of the NTs, meaning that NTs with smaller diameters are more resistant to mechanical wear. The elastic modulus of the TiO $\mathrm{NTs}$ with $15-\mathrm{nm}$ and 50-nm diameters is similar to that of the human bone.

Keywords: titanium dioxide $\left(\mathrm{TiO}_{2}\right)$ nanotubes, mechanical properties, elastic modulus, Vickers hardness

$\mathrm{Z}$ elektrokemično anodizacijo titanovega (Ti) substrata smo pripravili nanocevke iz titanovega dioksida $\left(\mathrm{TiO}_{2}\right) \mathrm{z}$ različno morfologijo. Pripravljene $\mathrm{TiO}_{2}$ nanocevke smo karakterizirali z rentgensko difrakcijsko spektroskopijo (XRD), Ramansko spektroskopijo, vrstično elektronsko mikroskopijo (SEM) in mikroskopijo na atomsko silo (AFM). Elastični modul (E) in Vickersova trdota (HV) Ti folije in $\mathrm{TiO}_{2}$ nanocevk z različno morfologijo, sta bili določeni s tehniko nanoindentacije. Elastični modul in Vickersova trdota naraščata $\mathrm{z}$ zmanjšanjem dolžine/premera $\mathrm{TiO}_{2}$ nanocevk, kar pomeni, da so nanocevke $\mathrm{z}$ nižjim premerom bolj odporne na mehansko obrabo. Elastični modul $\mathrm{TiO}_{2}$ nanocevk, s premerom $15 \mathrm{~nm}$ in $50 \mathrm{~nm}$, je podoben elastičnemu modulu človeških kosti.

Ključne besede: nanocevke iz titanovega dioksida $\left(\mathrm{TiO}_{2}\right)$, mehanske lastnosti, elastični modul, Vickersova trdota

\section{INTRODUCTION}

Titanium and its alloys are some of the most widely used implant materials because of their low toxicity, biocompatibility and mechanical properties. This is attributed to great tensile strength, resistance to body fluid effects, flexibility and high corrosion resistance. ${ }^{1}$ Although orthopaedic implants made of titanium alloys imply better results, the limited lifetime of these implants remains a major drawback. This limitation is due to the integration of the Ti-implant material with the juxtaposed bone tissue (osseointegration). ${ }^{2,3}$ To overcome osseointegration, the surface of titanium and its alloys can be modified to support cell adhesion and to encourage the formation of new bone at the interface between the implant surface and the bone tissue. ${ }^{4}$

*Corresponding author's e-mail:

ales.iglic@fe.uni-lj.si (Aleš Iglič)
Surface modification involves shifting topography from the micro to nanoscale or tailoring the nanoscale morphology so that the implant surface mimics the feature size of natural tissues and promotes cellular functions. ${ }^{5,6}$ Fabricating implant surfaces to have nanoscale dimensions is important because the feature size of all tissues is in the nano regime. For example, natural bone has inorganic constituent made up of 2-5 nm thickness and $20-25 \mathrm{~nm}$ wide hydroxyapatite crystals. ${ }^{7}$ Electrochemical anodization is one of the most cost-effective and convenient methods of nanoscaling the surface, ${ }^{8-10}$ which when performed under self-organized conditions results in $\mathrm{TiO}_{2}$ NTs grown directly on the Ti substrate material. ${ }^{1-9}$ In addition, the morphology of the nanotubes can be tailored for the desired application, e.g., the thickness of these layers can reach several hundreds of $\mu \mathrm{m}$, while the nanotube diameter can be adjusted from $10 \mathrm{~nm}$ to $800 \mathrm{~nm} .^{1,11}$ Among all the other properties of $\mathrm{TiO}_{2}$ nanostructures, the elastic modulus is a property that affects directly the implant stability. It is desirable that the 
metal's elastic modulus be as close as possible to that of the bone, because smaller differences between these values will result in a better transfer of stress, and avoiding the stress-shielding effect. ${ }^{12}$

The elastic modulus and hardness of the $\mathrm{TiO}_{2} \mathrm{NTs}$ layer plays an important role for the long-term stability of the implant - the most suitable technique to determine the elastic modulus of such thin $\mathrm{TiO}_{2}$ oxide layers is nano-indentation. However, the initial roughness and the probe geometry impose limitations. G. A. Crawford et al. ${ }^{13}$ have examined the deformation behaviour of a nanotube layer using nano-indentation tests with a Berkovich probe, that led to an indentation penetration higher than the thickness of the nanotube layer and wear marks on the indentation. B. Voltrova et al. ${ }^{14}$ studied the influence of the $\mathrm{TiO}_{2}$ nanotubes' diameter on the nanomechanical properties and found that a larger diameter of the nanotubes showed a lower elastic modulus and indentation hardness, and indicated that $\mathrm{TiO}_{2}$ nanotubes with a diameter close to $66 \mathrm{~nm}$ show the highest in-vitro benefits and therefore could be applied to improve bone implants' osseointegration.

In the present study, $\mathrm{TiO}_{2}$ NTs with different morphologies were obtained by using electrochemical anodization and the nano-indentation properties of different diameter nanotubes were studied based on the Oliver-Pharzz methodology.

\section{EXPERIMENTAL PART}

\subsection{Materials}

Titanium foil (Advent Research Materials, $0.1 \mathrm{~mm}$ thickness, $99.6 \%$ ), ethylene glycol (Fluka, $\geq 99.5 \%$ ), ammonium fluoride - $\mathrm{NH}_{4} \mathrm{~F}$ (Sigma Aldrich, 28.0-30.0 \%), hydrofluoric acid - HF (Sigma Aldrich, $\geq 40 \%$ ) acetone (Honeywell Riedel - de Haen, $99.5 \%$ ), ethanol (Sigma Aldrich, 96\%), deionized water (miliQ).

\subsection{Fabrication of $\mathrm{TiO}_{2}$ nanosurfaces}

The fabrication of the $\mathrm{TiO}_{2}$ NTs was carried out according to the electrochemical anodization method as in references, ${ }^{5-8}$ although using slightly different parameters, as described below. All the anodization experiments were carried out at room temperature $\left(\sim 20{ }^{\circ} \mathrm{C}\right)$ in a two-electrode system, using Ti foil as the working electrode and a platinum gauze as the counter electrode. Prior to anodization, the Ti foils were degreased by successive ultrasonication in acetone, ethanol and deionised water for $5 \mathrm{~min}$ each and dried in a nitrogen stream. An ethylene glycol-based electrolyte containing $\mathrm{NH}_{4} \mathrm{~F}$ $(0.35 w / \%)$ and $\mathrm{H}_{2} \mathrm{O}(1.7 w / \%)$ was used to grow the $\mathrm{TiO}_{2}$ NTs. This step was followed by removing the nanotubular layer via ultrasonication in deionised water and then by drying the pre-patterned sample in a nitrogen stream. This pre-patterned surface was subsequently used as a substrate in the anodization in the ethylene-gly- col-based electrolyte containing hydrofluoric acid (Table 1), used to grow homogeneous layers of self-arranged $\mathrm{TiO}_{2}$ NTs. The as-formed $\mathrm{TiO}_{2}$ NTs were immersed in ethanol for $2 \mathrm{~h}$ in order to remove the organic components from the electrolyte solution.

\subsection{Surface characterization of Ti nanostructures}

\subsubsection{Scanning Electron Microscopy (SEM)}

The morphology of the $\mathrm{TiO}_{2}$ nanostructures was observed using a field-emission scanning electron microscope - Hitachi FE-SEM S4800.

\subsubsection{Atomic Force Microscopy (AFM)}

Topographic features of the $\mathrm{Ti}$ foil and of the 100-nm-diameter $\mathrm{TiO}_{2}$ NTs were studied by Atomic Force Microscopy (Solver PRO, NT-MDT, Russia) in tapping mode in an air atmosphere. The samples were scanned with the standard Si cantilever (MikroMasch) at a constant force of $22 \mathrm{~N} / \mathrm{m}$ and resonance frequency of $325 \mathrm{kHz}$ (10 nm tip radius and $95 \mu \mathrm{m}$ tip length). The average surface roughness $\left(R_{\mathrm{a}}\right)$ was calculated from 10 different images made on $(5 \times 5) \mu \mathrm{m}$ areas.

\subsubsection{Scanning Probe Microscopy (SPM)}

The 3D topography of the titanium substrate surface was obtained by Hysitron's in-situ Scanning Probe Microscopy (SPM). Samples were scanned at a contact force of $1 \mu \mathrm{N}$ between a nano-indentation tip (diamond Berkovich) and a titanium substrate surface. In-situ SPM images were analysed using Hysitron's TriboView ${ }^{\mathrm{TM}}$ software. The average surface roughness $\left(R_{\mathrm{a}}\right)$ was calculated from a $(20 \times 20) \mu \mathrm{m}$ area. $3 \mathrm{D}$ topography of the $\mathrm{TiO}_{2}$ NTs' surface was obtained by Hysitron's in-situ SPM as well. Samples were scanned at a contact force of $0.05 \mu \mathrm{N}$ between the nano-indentation tip (diamond Cube Corner) and the $\mathrm{TiO}_{2}$ NTs' surface.

\subsubsection{Raman spectroscopy}

Raman spectra of all $\mathrm{TiO}_{2}$ samples were recorded using a Horiba Jobin-Yvon LabRAM HR800 Raman spectrometer equipped with $100 \times$ optical microscope, appropriate holographic notch filters and 1800 grooves $/ \mathrm{mm}$ holographic grating to provide the spectral resolution of $0.25 \mathrm{~cm}^{-1}$. A $632.8 \mathrm{~nm}$ helium-neon laser of $10-\mathrm{mW}$ power and 2- $\mu \mathrm{m}$ spot size was used to excite the samples. The spectra were taken in the wavenumber range of $100-1000 \mathrm{~cm}^{-1}$ with an exposure time of $2 \mathrm{~s}$.

\subsubsection{X-ray diffraction analysis $(X R D)$}

The crystal structure of the nanotube arrays was also confirmed using X-ray diffraction (XRD; PAN analytical D8 model) with $\mathrm{Cu}-K_{\alpha}$ radiation $\left(K_{\alpha}=0,15400 \mathrm{~nm}\right)$ in the $2 \theta$ range $20-80$.

\subsubsection{Nanoindentation studies}

A Hysitron TI 950 TriboIndenter ${ }^{\mathrm{TM}}$ nanomechanical test instrument was used for an assessment of the depth 
Table 1: Influence of the anodization conditions used on the morphology (diameter and length) of $\mathrm{TiO}_{2} \mathrm{NTs}_{\mathrm{s}}$

\begin{tabular}{|c|c|c|c|c|}
\hline Diameter $(\mathrm{nm})$ & Electrolyte & Potential $(\mathrm{V})$ & Anodization time $(\mathrm{h})$ & Length $(\mu \mathrm{m})$ \\
\hline 15 & $\mathrm{EG}+8 \mathrm{M} \mathrm{H}_{2} \mathrm{O}+0.2 \mathrm{M} \mathrm{HF}$ & 10 & 2.5 & 0.22 \\
\hline 50 & $\mathrm{EG}+8 \mathrm{M} \mathrm{H}_{2} \mathrm{O}+0.2 \mathrm{M} \mathrm{HF}$ & 20 & 2.5 & 1.10 \\
\hline 100 & EG+8 $\mathrm{M} \mathrm{H}_{2} \mathrm{O}+0.2 \mathrm{M} \mathrm{HF}$ & 58 & 2.5 & 3.50 \\
\hline
\end{tabular}

profiles of the mechanical properties on $\mathrm{TiO}_{2} \mathrm{NTs}$ (diameters $15 \mathrm{~nm}, 50 \mathrm{~nm}$ and $100 \mathrm{~nm}$ ) and Ti foil as a reference sample. The partial unload approach requires elastic-plastic deformation during gradual force cycles in order to analyse each unloading segment according the Oliver \& Pharr method ${ }^{15}$ Automated analysis plots the depth profile as discrete datasets. Based on the 1/10 rule, a coating of 100-nm thickness requires measurements at $<10 \mathrm{~nm}$ depth. ${ }^{16}$ A standard Berkovich tip area function $A(h)$, describing the shape of the indentation probe, was used: $A=24.5 h 2+C 1 h+C 2 h 1 / 2+C 3 h 1 / 4+C 4 h 1 / 8+$ $C 5 h 1 / 16$, where $C 1=7.6736 \mathrm{E}+3, C 2=-2.3046 \mathrm{E}+5, C 3$ $=1.9088 \mathrm{E}+6, C 4=-4.2845 \mathrm{E}+6$ and $C 5=2.6127 \mathrm{E}+6$. A Ti foil was used as reference to examine the nanomechanical properties of $\mathrm{TiO}_{2}$ NTs with diameters of $15 \mathrm{~nm}, 50 \mathrm{~nm}$ and $100 \mathrm{~nm}$.

Table 2: Number of $\mathrm{TiO}_{2}$ NTs in the contact with the Berkovich tip for contact depth $h c=5 \mathrm{~nm}$ and $h c=35 \mathrm{~nm}$ corresponding to the diagram in Figure 1 calculated from tip area function

\begin{tabular}{|c|c|c|}
\hline $\begin{array}{c}\text { Diameter } \\
(\mathrm{nm})\end{array}$ & $\begin{array}{c}\mathrm{TiO}_{2} \mathrm{NT} \text { in the contact } \\
h c=5 \mathrm{~nm} \text { (quantity) }\end{array}$ & $\begin{array}{c}\mathrm{TiO}_{2} \mathrm{NT} \text { in the contact } \\
h c=35 \mathrm{~nm} \text { (quantity) }\end{array}$ \\
\hline 15 & 39.44 & 224.56 \\
\hline 50 & 3.55 & 20.21 \\
\hline 100 & 0.89 & 5.05 \\
\hline
\end{tabular}

\section{RESULTS}

\subsection{Morphology of $\mathrm{TiO}_{2} \mathrm{NTs}$}

The morphology of the $\mathrm{TiO}_{2}$ NTs was evaluated with SEM. Analyses indicate the different diameters of the $\mathrm{TiO}_{2}$ NTs (Figure 2), i.e., $15 \mathrm{~nm}, 50 \mathrm{~nm}$ and $100 \mathrm{~nm}$ with standard deviations of $20 \%, 10 \%$ and $5 \%$, respectively, that were achieved by changing the anodization potential used in the electrochemical anodization (Table 1).

The topographical features of the $\mathrm{Ti}$ foil used as a substrate for the growth of NTs, as well as of the $\mathrm{TiO}_{2}$ NTs with $100 \mathrm{~nm}$ diameter were investigated by AFM,

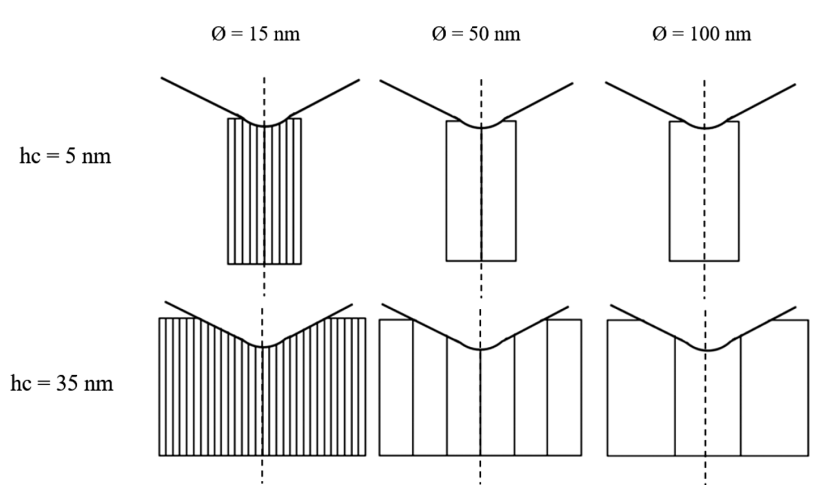

Figure 1: Schematic representation of contacts of the Berkovich indenter and $\mathrm{TiO}_{2}$ NTs in the nano-indentation test

as presented in Figure 3. The AFM analysis of Ti foil shows that the surface is not fully uniform, and some vertical distortions (vertical roughness) are observed with the AFM (Figure 3a). The average surface roughness measured on a $(5 \times 5) \mu \mathrm{m}$ area was about $35 \mathrm{~nm}$. On the surface of the 100-nm-diameter $\mathrm{TiO}_{2}$ NTs, features were clearly observed with the AFM, as the size of the nanotube diameter was sufficiently wide to enable the tip penetration inside the hollow nanotube interior, which was not possible for $\mathrm{TiO}_{2}$ NTs with a smaller diameter, such as the $\mathrm{TiO}_{2}$ NTs with $15 \mathrm{~nm}$ in diameter and $\mathrm{TiO}_{2}$ NTs with a $50 \mathrm{~nm}$ in diameter. The average roughness measured on a $(5 \times 5) \mu \mathrm{m}$ area for $\mathrm{TiO}_{2}$ NTs with $100 \mathrm{~nm}$ in diameter was about $47 \mathrm{~nm}$. However, it should be noted that this value is not entirely representative, as the AFM tip could only enter up to a limited length of the nanotube (as previously shown (8), the length of the $\mathrm{TiO}_{2}$ NTs with $100 \mathrm{~nm}$ in diameter is about $3.5 \mu \mathrm{m}$ as evaluated from SEM analysis). More importantly, the AFM results clearly show the opened hollow structure of the $\mathrm{TiO}_{2}$ NTs as well as the slight deviations in their height, about $200 \mathrm{~nm}$, as observed from the 3D image (Figure $3 \mathbf{b})$.
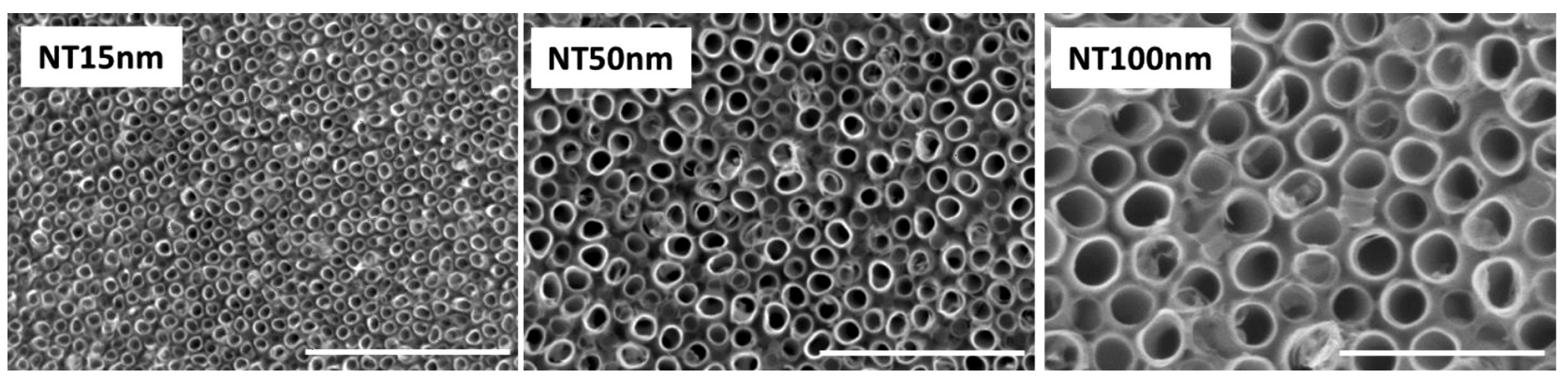

Figure 2: SEM images of the top surface of $\mathrm{TiO}_{2}$ NTs (size of the scale bar=500 nm) 

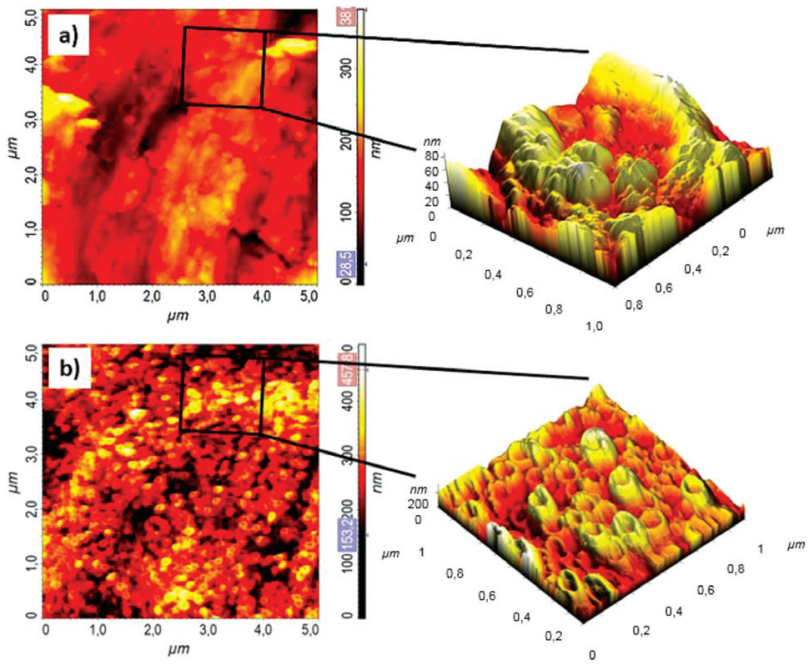

Figure 3: AFM images of: a) Ti foil, b) $\mathrm{TiO}_{2} \mathrm{NTs}$ with $100 \mathrm{~nm}$ in diameter. Zoomed region (along vertical $z$-direction) shows further topological details

The 3D topography of the titanium substrate (Ti foil) surface is also obtained by in-situ SPM, see Figure 4a and shows a non-negligible roughness of the sample. The average roughness of the Ti substrate surface was around $49 \mathbf{n m}$. Similarly, Figures $\mathbf{4 b}$ and $\mathbf{4 c}$ show the in-situ SPM images of 100-nm-diameter $\mathrm{TiO}_{2}$ nanotubes surface.

\subsubsection{Crystal structure of $\mathrm{TiO}_{2} \mathrm{NTS}$}

Raman spectroscopy provides very important information about the Raman-active vibrational modes related to the Ti-Ti, Ti-O and $\mathrm{O}-\mathrm{O}$ bonds in $\mathrm{TiO}_{2}$. It is well known that anatase $\mathrm{TiO}_{2}$ gives a strong Raman signal at $144 \mathrm{~cm}^{-1}$ followed by low intensity peaks at (197, 394-399, 513/514, 519 and 635-641) $\mathrm{cm}^{-1}$, whereas rutile $\mathrm{TiO}_{2}$ gives Raman signals at 143, 236/242, 446/447 and $610 / 613 \mathrm{~cm}^{-1} \cdot{ }^{17-19}$ The Raman spectra for all $\mathrm{TiO}_{2}$ samples of different diameters are presented in Figure 5. All the spectra show broad bands and no clear spectral characteristics of anatase or the rutile phase of $\mathrm{TiO}_{2}$. Thus, the $\mathrm{TiO}_{2}$ nanotubes produced in our electrochemical anodization process are of an amorphous nature 20 The broad bands appearing near $284 \mathrm{~cm}^{-1}$ and in the

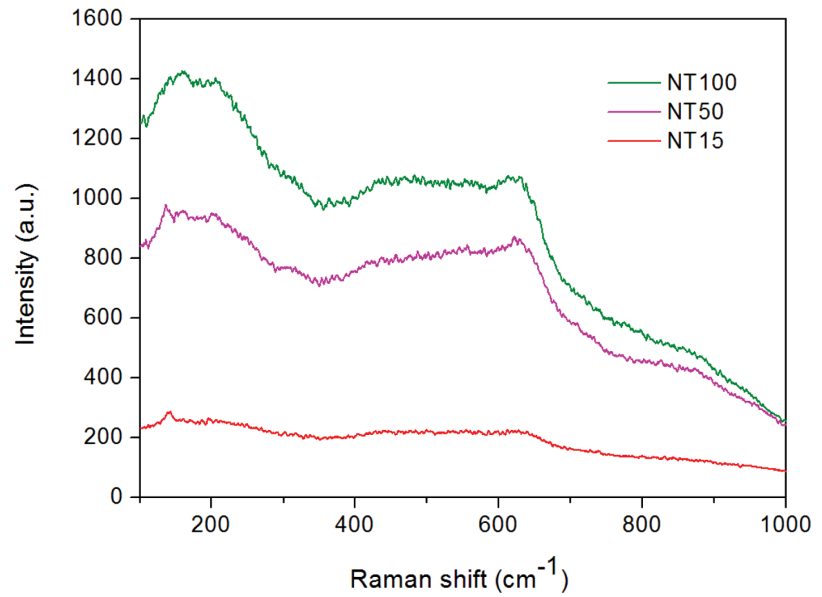

Figure 5: Raman spectra of $\mathrm{TiO}_{2}$ NTs with various diameters. $\mathrm{T}=\mathrm{Ti}$ substrate

range $430-630 \mathrm{~cm}^{-1}$ in all the spectra can be assigned to $\mathrm{O}-\mathrm{O}$ interactions consistent with the $\mathrm{TiO}_{6}{ }^{8-}$ octahedral structure and the Ti-O interactions, respectively.(19) A sharp peak appearing at $143 / 144 \mathrm{~cm}^{-1}$ in the spectrum of the $\mathrm{TiO}_{2}$ NTs with 15-nm diameter can be considered to arise from slightly rutile/anatase phase of $\mathrm{TiO}_{2}$ nanotubes due to Ti-Ti covalent interactions. This feature tends to cease, and the amorphous nature tends to be more prominent as the tube diameter increases to $50 \mathrm{~nm}$ and $100 \mathrm{~nm}$. The weak band near $840 \mathrm{~cm}^{-1}$ can be assigned as the first overtone of the $143 / 144 \mathrm{~cm}^{-1}$ band. ${ }^{21}$

The XRD patterns for the different diameter as-grown $\mathrm{TiO}_{2}$ NT arrays as well as for the substrate material ( $\mathrm{Ti}$ foil) are presented in Figure 6. After the electrochemical anodization, no crystalline phase is detected for the as-grown NTs, thus further confirming their amorphous state. Comparing the patterns of the $\mathrm{TiO}_{2}$ NTs with that of the substrate materials only peaks characteristic for the $\mathrm{Ti}$ substrate materials are detected. These results are in agreement with the previous report. ${ }^{22}$

\subsubsection{Nanoindentation studies}

The mechanical stability of the implant is an essential factor to maintain its long-term success. In the present study, the mechanical properties of $\mathrm{TiO}_{2}$ NTs with differ-

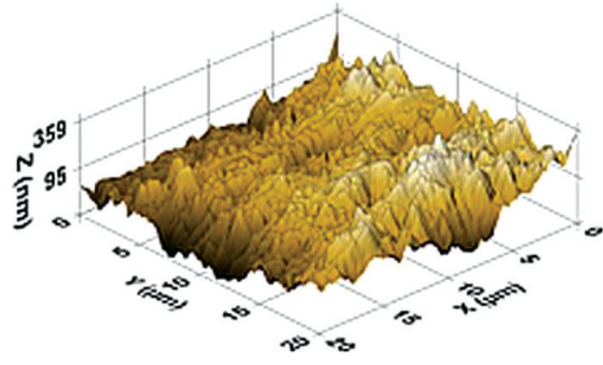

a)

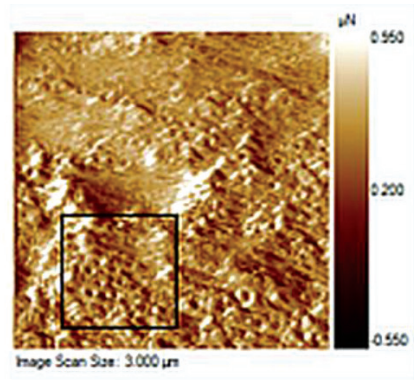

b)

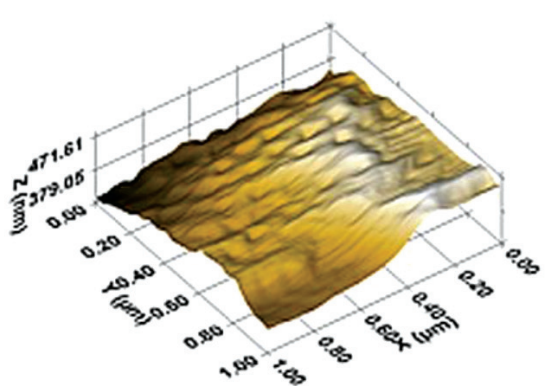

c)

Figure 4: In-situ SPM images: a) 3D topography of titanium foil, b) map of gradients of forces obtained from $\mathrm{TiO}_{2} \mathrm{NTs}_{\mathrm{s}}$ with $100 \mathrm{~nm}$ in diameter sample and c) 3D topography of the area demarcated by a black square in the picture from b) 


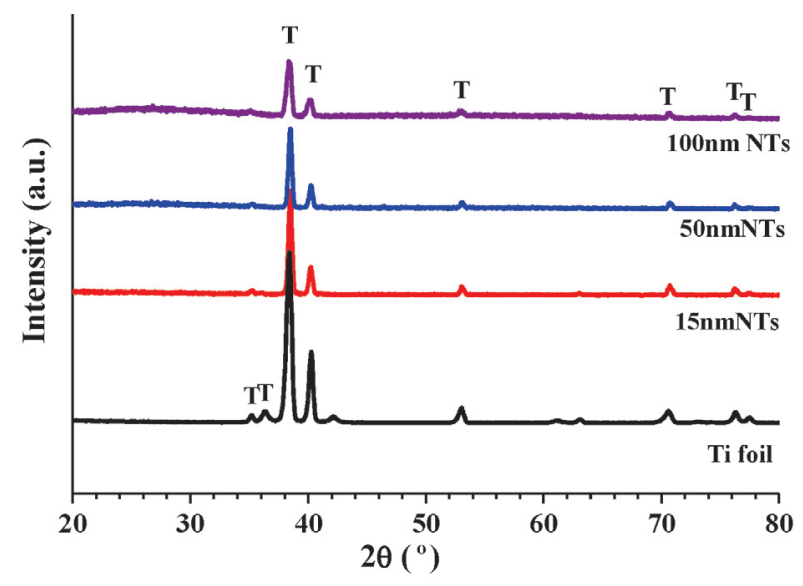

Figure 6: X-ray diffraction (XRD) patterns of $\mathrm{Ti}$ substrate and $\mathrm{TiO}_{2}$ NTs with various diameters $(\mathrm{T}=\mathrm{Ti}$ substrate)

ent lengths and diameters (Table 1) were measured with a Berkovich indenter. Values of $E$ and HV (calculated from apparent indentation hardness HIT) were calibrated from contact depths $h c=5 \mathrm{~nm}$ and $h c=35 \mathrm{~nm}$, respectively (Figure 7). ${ }^{16}$

In this work, the elastic modulus increases with decreasing diameter of the $\mathrm{TiO}_{2}$ NTs, and with decreasing length as well. The evaluated $E$ is $8.7 \pm 4.2 \mathrm{GPa}$ for $\mathrm{TiO}_{2}$ NTs with $100 \mathrm{~nm}$ in diameter, $10.3 \pm 4.6 \mathrm{GPa}$ for $\mathrm{TiO}_{2}$ NTs with $50 \mathrm{~nm}$ in diameter and 19.2 $\pm 4.3 \mathrm{GPa}$ for $\mathrm{TiO}_{2}$ NTs with $15 \mathrm{~nm}$ in diameter (Figure 8). Y.N. Xu et al. ${ }^{23}$ reported an elastic modulus of $5.1 \mathrm{GPa}$ for longer $\mathrm{TiO}_{2}$ NTs $(\sim 8.5 \mu \mathrm{m})$, with a diameter of $\sim 199 \mathrm{~nm}$ and a wall thickness of $\sim 14.3 \mathrm{~nm}$. However, the elastic modulus of the 15-nm- and 50-nm-diameter $\mathrm{TiO}_{2}$ NTs evaluated in the present study is similar to that of bone, which is $11-30 \mathrm{GPa}^{24}$

It has been reported that the hardness of films is dependent on their adhesion to the substrate, i.e., the higher the hardness, the higher the adhesion. ${ }^{25}$ In present study, $H v$ increases with decreasing length/diameter of the NTs; therefore, $\mathrm{TiO}_{2} \mathrm{NTs}$ of $15 \mathrm{~nm}$ in diameter exhibit the highest adhesion strength to the substrate (Figure 9). Since adhesion is higher for smaller diameter $\mathrm{TiO}_{2} \mathrm{NTs}$,

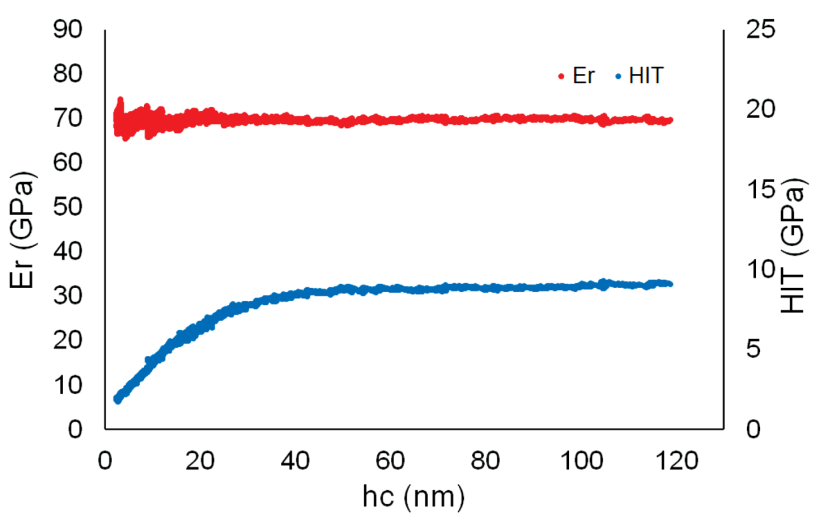

Figure 7: Calibration values of $E$ and $H$ vs. contact depth on fused quartz sample

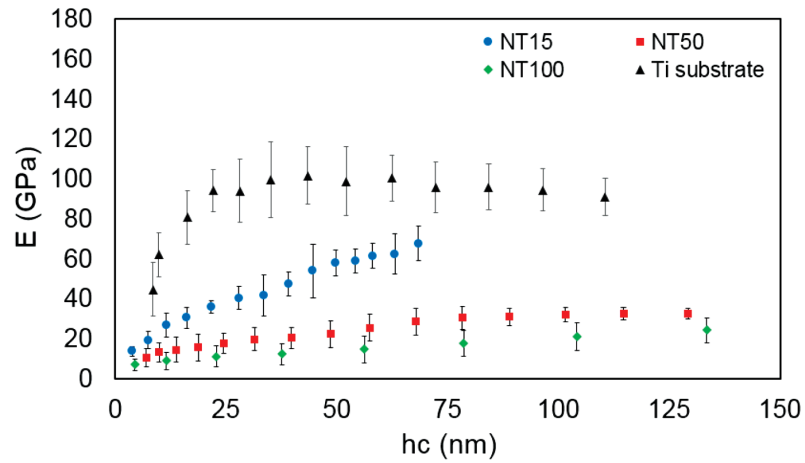

Figure 8: Depth profile of Young's modulus

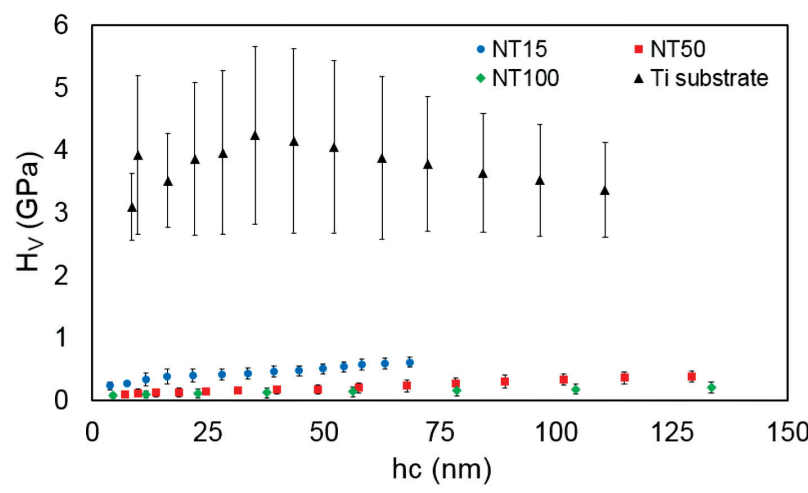

Figure 9: Depth profiles of calculated Vickers hardness. The Vickers hardness was calculated from the measured apparent indentation hardness $H V(\mathrm{GPa})=0.92666^{*} \mathrm{HIT}$

it follows that such nanostructures are also more resistant to mechanical wear. ${ }^{26}$ However, the $H v$ values are consistent with the existing reported values. For instance, Y. N. $\mathrm{Xu}$ et $\mathrm{al}^{23}$ reported a hardness of $0.094 \mathrm{GPa}$ for longer $\mathrm{TiO}_{2}$ NTs (diameter: approx. $199 \mathrm{~nm}$, wall thickness: 1 approx. $14.3 \mathrm{~nm}$ and length: approx. $8.5 \mu \mathrm{m}$ ). In the present study, $\mathrm{Hv}$ is $0.45 \pm 0.09 \mathrm{GPa}$ for $\mathrm{TiO}_{2} \mathrm{NTs}$ with $15 \mathrm{~nm}$ in diameter, $0.16 \pm 0.06 \mathrm{GPa}$ for $\mathrm{TiO}_{2}$ NTs with $50 \mathrm{~nm}$ in diameter and $0.12 \pm 0.08 \mathrm{GPa}$ for $\mathrm{TiO}_{2} \mathrm{NTs}$ with $100 \mathrm{~nm}$ in diameter. The average $H v$ of the Ti foil is $3.8 \pm 0.3 \mathrm{GPa}$.

\section{CONCLUSIONS}

Amorphous, as-formed $\mathrm{TiO}_{2}$ NTs with diameters of $15 \mathrm{~nm}, 50 \mathrm{~nm}$ and $100 \mathrm{~nm}$ were prepared by electrochemical anodization. The nano-indentation studies revealed that the elastic modulus and Vickers hardness of the $\mathrm{TiO}_{2}$ NTs increased with the decreasing length/diameter of the $\mathrm{TiO}_{2}$ NTs (as a reference, a Ti foil was measured). The elastic modulus of $15 \mathrm{~nm}$ and $50 \mathrm{~nm}$ diameter $\mathrm{TiO}_{2}$ nanotubes is similar to the elastic modulus of the human bone. The Vickers hardness of the 15-nm-diameter $\mathrm{TiO}_{2}$ nanotubes exhibits the highest adhesion strength to the substrate. These results indicate that the $\mathrm{TiO}_{2}$ NTs with smaller diameters are more resistant to mechanical wear. Such materials can be used in medical 


\section{KULKARNI et al.: MECHANICAL PROPERTIES OF ANODIC TITANIUM DIOXIDE NANOSTRUCTURES}

applications, such as orthopaedic implants or drug-delivery systems.

\section{Acknowledgment}

The authors would like to acknowledge the Slovenian Research Agency for financial support, grants No. Z3-4261 and J3-9262 and Slovenian Ministry of Education, Science and Sport grant "Public call for encouraging young investigators at the beginning of their career $2.0 "$, No. 5442-15/2016/18.

\section{REFERENCES}

${ }^{1}$ P. Roy, S. Berger, P. Schmuki, $\mathrm{TiO}_{2}$ Nanotubes: Synthesis and Applications, Angew. Chem. Int. Ed., 50 (2011) 13, 2904-2939, doi:0.1002/anie.201001374

${ }^{2}$ V. Sansone, D. Pagani, M. Melato, The effects on bone cells of metal ions released from orthopaedic implants, Clin. Cases Miner. Bone Metab., 10 (2013) 1, 34-40, doi:10.11138/ccmbm/2013.10.1.034

${ }^{3}$ M. Izmir, B. Ercan, Anodization of titanium alloys for orthopedic applications, Front. Chem. Sci. Eng., 13 (2019) 1, 28-45, doi:10.1007/ s11705-018-1759-y

${ }^{4}$ E. P. Su, D. F. Justin, C. R. Pratt, V. K. Sarin, V. S. Nguyen, S. Oh, \& S. Jin, Effects of titanium nanotubes on the osseointegration, cell differentiation, mineralisation and antibacterial properties of orthopaedic implant surfaces, The Bone \& joint J., 100 (2018), 9-16, doi:10.1302/0301-620X.100B1.BJJ-2017-0551.R1

${ }^{5}$ M. Kulkarni, A. Flašker, M. Lokar, K. Mrak-Poljšak, A. Mazare, A. Artenjak, S. Čučnik, S. Kralj, A. Velikonja, P. Schmuki, Binding of plasma proteins to titanium dioxide nanotubes with different diameters, Int. J. Nanomed., 10 (2015) 1, 1359-1373, doi:10.2147/IJN. S77492

${ }^{6}$ K. S. Brammer, S. Oh, C. J. Cobb, L. M. Bjursten, H. V. D. Heyde, S. Jin, Acta Biomater., 5 (2009) 8, 3215-3223, doi:10.1016/j.actbio. 2009.05.008

${ }^{7}$ L. C. Palmer, C. J. Newcomb, S. R. Kaltz, E. D. Spoerke, S. I. Stupp, Biomimetic systems for hydroxyapatite mineralization inspired by bone and enamel, Chem. Rev., 108 (2008) 11, 4754-4783, doi: $10.1021 / \mathrm{cr} 8004422$

${ }^{8}$ M. Kulkarni, Y. Patil-Sen, I. Junkar, C. V. Kulkarni, M. Lorenzetti, A. Iglič, Wettability studies of topologically distinct titanium surfaces, Coll. and Surf. B: Biointerfaces, 129 (2015), 47-53, doi:10.1016/j.colsurfb.2015.03.024

${ }^{9}$ M. Kulkarni, A. Mazare, E. Gongadze, Š. Perutkova, V. Kralj-Iglič, I. Milošev, P. Schmuki, A. Iglič, M. Mozetič, Titanium nanostructures for biomedical applications, Nanotechnology, 26 (2015) 6, 062002 , doi:10.1088/0957-4484/26/6/062002

${ }^{10}$ D. Kowalski, D. Kim, P. Schmuki, $\mathrm{TiO}_{2}$ nanotubes, nanochannels and mesosponge: Self-organized formation and applications, Nano today, 8 (2013) 3, 235-264, doi:10.1016/j.nantod.2013.04.010

${ }^{11}$ K. Lee, A. Mazare, P. Schmuki, One-Dimensional Titanium Dioxide Nanomaterials: Nanotubes, Chemical reviews, 114 (2014) 19, 9385-9454, doi:10.1021/cr500061m
${ }^{12}$ M. Niinomi, M. Nakai, Titanium-Based Biomaterials for Preventing Stress Shielding between Implant Devices and Bone, Int. J. Biomaterials, 2011 (2011), doi:10.1155/2011/836587

${ }^{13}$ G. A. Crawford, N. Chawla, K. Das, S. Bose, A. Bandyopadhyay, Microstructure and deformation behavior of biocompatible $\mathrm{TiO}_{2}$ nanotubes on titanium substrate, Acta Biomater., 3 (2007) 3, 359-367, doi:10.1016/j.actbio.2006.08.004

${ }^{14}$ B. Voltrova, V. Hybasek, V. Blahnova, J. Sepitka, V. Lukasova, K. Vocetkova, V. Sovkova, R. Matejka, J. Fojt, L. Joska, M. Daniel, E. Filova, Different diameters of titanium dioxide nanotubes modulate Saos-2 osteoblast-like cell adhesion and osteogenic differentiation and nanomechanical properties of the surface, RSC Advances, 9 (2019) 20, 11341-11355, doi:10.1039/c9ra00761j

${ }^{15}$ G. Pharr, W. Oliver, Measurement of Thin Film Mechanical Properties Using Nanoindentation, MRS Bulletin, 17 (1992) 7, 28-33, doi:10.1557/S0883769400041634

${ }^{16}$ B. STANDARD, B. ISO, Metallic materials - Instrumented indentation test for hardness and materials parameters, (2007)

${ }^{17}$ V. Castrejón-Sánchez, E. Camps, M. Camacho-López, Quantification of phase content in $\mathrm{TiO}_{2}$ thin films by Raman spectroscopy, Superficies y vacío, 27 (2014) 3, 88-92

${ }^{18}$ F. Tian, Y. Zhang, J. Zhang, C. Pan, Raman spectroscopy: a new approach to measure the percentage of anatase $\mathrm{TiO}_{2}$ exposed (001) facets, J. Phys. Chem. C, 116 (2012) 3, 7515-7519, doi:10.1021/ jp301256h

${ }^{19}$ F. D. Hardcastle, Raman spectroscopy of titania $\left(\mathrm{TiO}_{2}\right)$ nanotubular water-splitting catalysts. Journal of the Arkansas academy of science, 65 (2011) 1, 43-48

${ }^{20}$ H. Yin, Y. Wada, T. Kitamura, S. Kambe, S. Murasawa, H. Mori, T. Sakata, S. Yanagida, Hydrothermal synthesis of nanosized anatase and rutile $\mathrm{TiO}_{2}$ using amorphous phase $\mathrm{TiO}_{2}$, J. Mater. Chem., 11 (2001) 6, 1694-1703, doi:10.1039/b008974p

${ }^{21}$ U. Balachandran, N. G. Eror, Raman spectra of titanium dioxide. Journal of Solid State Chemistry, 42 (1982) 3, 276-282, doi:10.1016/ 0022-4596(82)90006-8

${ }^{22}$ G. K. Mor, O. K. Varghese, M. Paulose, K. Shankar, C. A. Grimes, A review on highly ordered, vertically oriented $\mathrm{TiO}_{2}$ nanotube arrays: Fabrication, material properties, and solar energy applications. Solar Energy Materials and Solar Cells, 90 (2006) 14, 2011-2075, doi:10.1016/j.solmat.2006.04.007

${ }^{23}$ Y. N. Xu, M. N. Liu, M. C. Wang, A. Oloyede, J. M. Bell, C. Yan, Nanoindentation study of the mechanical behavior of $\mathrm{TiO}_{2}$ nanotube array, Journal of Applied Physics, 118 (2015) 14, 145301, doi:10.1063/1.4932213

${ }^{24}$ J. Y. Rho, T. Y. Tsui, G. M. Pharr, Elastic properties of human cortical and trabecular lamellar bone measured by nanoindentation, Biomaterials, 18 (1997) 20, 1325-1330, doi:10.1016/S0142-9612 (97)00073-2

${ }^{25}$ D. Stone, W. R. LaFontaine, P. Alexopoulos, T. W. Wu, C. Y. Li, An investigation of hardness and adhesion of sputter-deposited aluminum on silicon by utilizing a continuous indentation test, J. Materials Research, 3 (1988) 1, 141-147, doi:10.1557/JMR.1988.0141

${ }^{26}$ S. A. Alves, A. L. Rossi, A. R. Ribeiro, F. Toptan, A. M. Pinto, T. Shokuhfar, J.-P. Celis, L. A. Rocha, Improved tribocorrosion performance of bio-functionalized $\mathrm{TiO}_{2}$ nanotubes under two-cycle sliding actions in artificial saliva, Journal of the mechanical behavior of biomedical materials, 80 (2018), 143-154, doi:10.1016/j.jmbbm.2018. 01.038 